\title{
The unresolved problem of determining the forest interest rate
}

\author{
Krzysztof Adamowicz \\ Poznań University of Life Sciences, Faculty of Forestry, Wojska Polskiego 71C, 60-625 Poznań, Poland, \\ e-mail: adamowic@up.poznan.pl
}

\begin{abstract}
Valuation of forests and their components is a significant problem, both for science and practice. At present, in many countries, the market of forest property is limited. As a result, no conclusions may be inferred on the forest value based on the information on forest purchase and sale transactions. In this situation, we apply static methods of forest valuation. The problem of forest statics has been discussed for years (e.g., Brukas et al. 2001; Chang 1983, 2001; Dieter 2001; Hartman 1976; Manley and Bare 2001; Mohring 2001; Zhang 2001; Viitala 2016). Static methods of forest valuation are well known. In the construction of the proposed mathematical formula (Eq. 6), the Faustmann theory was applied, concerning the economic equilibrium in forestry. Numerous modifications of his equation for economic equilibrium were used to develop, for example, an income method for forest valuation based on discounting the final value or prolongation of initial value. The forest interest rate is a key element in these equations. At present, there are no procedures for the establishment of this interest rate, which would be generally accepted by the scientific community. Therefore, the article presents and discusses selected concepts for determining the forest interest rate.
\end{abstract}

\section{KeY WORDS}

forestry economics, value, forestry rate

\section{INTRODUCTION}

Efforts to give forestry a rational economic basis are almost as old as regulated forestry itself. During the last two centuries, many well-known forestry scientists and practitioners have worked on this topic (Möhring 2001). Valuation of assets is a significant element in the realisation of contemporary politics and economy. Literature on the subject presents several definitions of value. When talking about 'value', the term should either be specified or be understood as an 'umbrella concept', comprised of several incommensurable kinds of values
(Holland 2011). Within the broader sense of 'value' in relation to environmental aspects, it was analysed by Pearce and Seccombe-Hett (2000) and Spangenberg and Settele (2016).

The concept of valuation is directly connected with value. Valuation is the process of value attribution; every valuation is based on specific ethics determining the value system applied and uses its own 'language of valuation' (Martinez-Alier et al. 1998; Martinez-Alier 2001). Most typically, valuation is connected with monetary representation of value. Monetary valuation of ecosystem services is a widely used approach to quan- 
tify benefits supplied by the natural environment to the society (Ansink et al. 2008).

The greatest interest in forest valuation was observed around the 1850's, when capital was acknowledged as the dominant production factor and forest land was considered to be the only capital engaged in forest production. At the same time, the adopted sustainable and continuous utilisation of timber resources limits the forest market turnover. This results in the disturbance of its marker prices. In such a situation, valuation methods are developed for forest land and stands based on income generated by forest income from timber sales. At present, in many countries, such as Poland, forest land turnover is still limited. Thus, in forest valuation, static methods may be applied.

In forest statics, the primary methodological premise in forest valuation, including its basic components, that is, forest land and the stand growing on it, is the economic equilibrium equation formulated by Faustmann (1849). As it was reported by Viitala (2016), a common notion in forest and natural resource economics is that the celebrated 'Faustmann's formula' was discovered by a young Hessian forester Martin Faustmann in 1849 and that the 'Faustmann's rule' or Faustmann-Pressler solution to the optimal rotation age was derived from it a decade later by a distinguished professor of forest mathematics Max Robert Pressler (e.g., Crocker et al. 2002; Gan et al. 2001)

Numerous modifications of this equation were used to develop the income method of forest valuation. Forest valuation is a science and an art. It is a science, since it applies proper methods and formulas, and it is an art, because we need to select a valuation method for the purpose of its valuation and to characteristics of stands such as tree age and species as well as the method of its generation and management (since every stand is unique). Thus, forest economics takes a cautious approach to stand valuation, as it is based on estimation. It is always an estimate, despite the application of appropriate methods and formulas.

\section{Static Methods Of Forest Valuation}

In this paper, the primary object of interest is the forest interest rate. For this reason, it presents only the most important observations concerning methodologi- cal foundations for the estimation of forest value using static methods. A detailed review of the application of static forest valuation methods was given in literature on the subject (Brukas at el. 2001). In all the presented opinions, static methods are based on the common assumption that forest is a capital, on which certain interest or income (rent) are dependent.

The procedure is based on the assumption that if the initial capital, reflected in the costs of forest culture establishment or land value (K0), will be deposited for a specific number of years at a specific interest rate ( $p)$, the value of this capital (Ki) at the age of the estimate (i) may be calculated using the following prolongation formula:

$$
\mathrm{Ki}=\mathrm{K} 0 \times(1,0 \mathrm{p})^{\mathrm{i}}
$$

Also, if we know the final value of stands $\left(\mathrm{K}_{\mathrm{u}}\right)$, expressed in the value of sold timber, we may calculate the value of stands at any given age (i) by discounting it:

$$
\mathrm{Ki}=\frac{\mathrm{K}_{\mathrm{u}}}{(1.0 \mathrm{p})^{\mathrm{i}}}
$$

As mentioned above, the foundations for forest statics were created by Faustmann, who in 1849 published a formula for economic equilibrium of forest economy. For many years, this concept shaped the economic model of forest economy in which forest land (land capital) is the basic production factor. Income from forest comprised interest on this capital. In simple terms, the Faustmann formula is as follows:

$$
\mathrm{Du}=\mathrm{B} \times\left(1.0 \mathrm{p}^{\mathrm{u}}-1\right)+\mathrm{c} \times 1.0 \mathrm{p}^{\mathrm{u}}
$$

It results from the presented formula that forest economy is in equilibrium when income from final cutting $(\mathrm{Du})$ is equal to interest on land capital $\left[\mathrm{B} \times\left(1.0 \mathrm{p}^{\mathrm{u}}-1\right)\right]$ charged for the entire production period (rotation) of the stand (u) and regeneration costs (c) with interest $\left(\mathrm{c} \times 1.0 \mathrm{p}^{\mathrm{u}}\right)$. In some countries, this formula is still used to determine the age of financial cutting maturity of the stands.

However, the paradigm of environmentally friendly forest economy adopted, for example, in the Central Europe, results in a much greater cutting age of the stands than that produced by the economic equilibrium equa- 
tion. Nevertheless, the economic equilibrium equation may be used in forest valuation, particularly since the stand is a source of positive cash flows (revenue) and negative cash flows (costs). These cash flows are generated at different, occasionally very distant time points (equal to the rotation age). An adequate method to compare and aggregate these cash flows is to update their value. The significance of the Faustmann formula and condition is not restricted to forestry. As it was pointed out by (Gaffney 2008), the Faustmann formula ostensibly deals with timber growth, but can be adapted to deal with all capital assets, with any time-patterns of inputs and outputs whatsoever. Another relevant point is that although the economic problem of handling natural resources is as old as civilization (Lowry 1965), the Faustmann model (encompassing both the formula and the condition) has been regarded as perhaps the oldest formal description of natural resource use that is still considered to be theoretically valid (Tahvonen and Salo 1999). It appears that in early natural resource economics, only the works of Johann Heinrich von Thünen in the year 1826 and Thünen in the year 1863 contain similar theoretical sophistication with regard to capital valuation and marginal analysis as the writings of Faustmann, Pressler and other early German forest economists (Viitala 2016).

Forest capital (forest economy and its assets) need to be seen as any other market good, subjected to the same economic and financial principles as well as formal and legal valuation rules. For this reason, the capital solutions connected with economic forest valuation should be considered when developing theoretical foundations for forest valuation. This is particularly because - as it was shown by Paua Anthon Samuelson, awarded the Alfred Nobel Bank of Sweden prize in economics - the Faustmann concept concerning forest valuation may also be applied in new areas of economic activity (Płotkowski 2010). Stand value may be estimated by the capitalisation of cash flows and updating the future (expected) revenue and net costs. Applying the theory of money value, we may determine the value of a stand at any specific age (NPV) as a sum of updated (to that age) net cash flow (NCF) in individual periods (years) of its life (Zając and Świętojański 2002). Net cash flows constitute the difference between the future revenues and costs of their generation and discounted interest:

$$
\mathrm{NPV}_{\mathrm{i}}=\mathrm{K} 0+\sum_{\mathrm{i}=0}^{\mathrm{u}} \frac{\mathrm{NCF}_{\mathrm{i}}}{(1+\mathrm{p})^{\mathrm{i}}}
$$

The Faustmann theory of discounted cash flow analysis was presented by Manley and Bare (2001). They described three valuation approaches: compounding costs, compounding discounting annuities and discounting future cash flows (Manley and Bare 2001). At present, the method of forest value estimation is not a problem. It is rather the determination of an adequate interest rate.

\section{FOREST INTEREST RATE}

In the 20th century, at the turn of the 1980's and 1990's, Podgorski and Kikayi (1996) investigated the empirical determination of the volume of forest interest rate (p). They stated that a reliable method to determine the forest interest rate is provided by the annual cutting budget $(\mathrm{Eu})$ in relation to the structure of standing timber resources (Znp):

$$
\mathrm{p}=\frac{\mathrm{Eu}}{\mathrm{Znp}}
$$

In financial terms, they proposed to calculate the volume of forest interest rate (p) from the ratio of the value of the assumed yield and the value of standing timber resources.

Podgórski and Kikayi (1996) were of the opinion that replacing the category of net income from forest economy with the volume or value of the allowable annual cut is more consistent with the contemporary forest economy practice, while the modified forest interest rates may be used for monetary valuation of both forest land and standing timber resources. In Poland, the forest interest rate calculated in this manner is approximately $2 \%$.

Some literature sources present an opinion that interest rate is a comparative measure, which may be used to determine value and as a result of such an economic character, it has to be uniform in all valuation cases. A discussion on this subject was presented by Molenda (1945), who indicated that some researchers, such as Endres (1919), assumed a constant value of interest rate at $3 \%$. Nördlinger (1805) claimed that the conventional (risk adjusted) discount rate to be applied on farmland 
investments was $3 \%$ and on pure money capital $5 \%$ - for this reason, he felt it reasonable if it was something in between for forest; thus, as an integer, 4\%. Lehr and Borggreve (1879) were strong opponents of a low interest rate and for permanent forest culture he applied rates of $4-6 \%$, while for less permanent cultures they applied rates of up to $10 \%$. Some researchers express an opinion that in the case of capital, with an extensive productive life interest rate, (p) is $1-3 \%$ (Zydron et. al 2012). In turn, Piekutin and Skreta (2012) claimed that the level of forest interest rate decreased from $5 \%$ in the early 1800 's to approx. $1 \%$ at present.

\section{Proposal for establishment OF FOREST INTEREST RATE}

It is stressed that discount rate is viewed as one of the most important decision parameters, and in this regard, it should be given to non-timber forest outputs, social and institutional settings and other factors (Brukas et al. 2001). Additionally, the current forest economy practice does not impose economic aspects as a priority, which is associated with ecological considerations. Many studies have been undertaken to determine the optimal forest rotation length under different scenarios since the advent of the Faustmann's formula. Some were focused on the optimal rotation age with the consideration of only timber value (Chang 1983; Mcconnell et al. 1983; Newman et al. 1985). Others searched for the optimal rotation age with the inclusion of both timber and non-timber benefits (Calish et al. 1978; Hartman 1976; Vankooten et al. 1995). These studies have provided important guidelines on when to cut trees in even-aged plantations. However, their applications in uneven-aged, or natural forests, are limited because age is no longer an appropriate variable under such circumstances (Gan et al. 2001). As a consequence, the interest rate is no longer of great importance as an element determining optimal rotation (Price 1987). However, it may be used in stand valuation.

Forest interest rate for the purpose of forest valuation should be determined in relation to actual market data connected with the specific forest economy. Over the entire stand life cycle, we may easily obtain at two time points reliable and comprehensive financial information concerning the whole area occupied by a given stand. They are costs of establishment of the forest culture and revenue from timber sales from the mature stand. We may ask here whether the volume of revenue or rather income from timber sales should be applied in methodological discussions. Since we intend to valuate standing stands at any given age, it is proposed to base the calculations on data concerning revenue from timber sales. Revenue is informative of the value of standing timber.

In this proposal, the estimation of value is based on information that may be called marginal data (costs of forest culture establishment and revenue from timber sales). Based on this information, after the transformation of conventional formulas of prolongation (Eq. 1) or discounting (Eq. 2), we may calculate the volume of forest interest rate. Assuming that at maturity (u), the expected value (Ki) will be equal to the value of sales $(\mathrm{Ku})$, the value of forest interest rate is calculated as:

if

$$
\mathrm{i}=\mathrm{u}
$$

then

$$
\mathrm{Ki}=\mathrm{Ku}=\mathrm{K} 0 \times(1.0 \mathrm{p})^{\mathrm{u}}=\frac{\mathrm{K}_{\mathrm{u}}}{(1,0 \mathrm{p})^{\mathrm{u}}}
$$

and thus,

$$
\mathrm{p}=\left[\left(\sqrt[u]{\frac{\mathrm{Ku}}{\mathrm{K} 0}}\right)-1\right] \times 100 \%
$$

Due to the application of marginal measures, the applied value of the stand at the age of estimation (Ki) has to be equivalent to the value of the stand at maturity. In other words, the age of stand maturity is the age of estimation $(i=u)$. In view of the fact that we may easily record regeneration costs for individual forested areas (k0) and we may obtain comprehensive information on revenue from timber sales $(\mathrm{Ku})$, forest interest rate may be calculated separately for individual species and quality classes (with quality class understood as an indicator determining the potential productivity for a given species in a specific forested area). In the calculations, we need to use the current average costs of forest regeneration and revenue from timber sales from a given region or country. In order 
to collect data, we may use forest reporting statistics. Historical data concerning stand regeneration should not be used, since the actual costs incurred for regeneration of a specific forested area were incurred over periods frequently exceeding 100 years, that is, under completely different economic conditions. Application of current information on forest regeneration from the year, from which the information on revenue from timber sales is obtained, is an automatic update of costs to current economic conditions. Obviously in considerations on the volume of forest interest rate and also as a result on the forest value, we need to consider costs and revenue in relation to individual species and forest site types specified, for example, in the European Forest Type Classification.

In view of the above, for example, the value of forest interest rate was calculated for pine stands growing on soils differing in production potential (quality classes from Ia to V). For experimental purposes, we assumed 100 years to be the rotation age of these stands. Calculations were based on information presented by the Central Statistical Office of Poland for the State Forests National Forest Holding (PGL LP) in 2014 and the financial statement of this organization. The State Forests is a state organizational unit with no legal entity and it represents the State Treasury of the Republic of Poland in management of property. PGL LP operates as a financially independent entity. The area administered by PGL LP according to the status of 31 December 2014 is a total of 7,605,178.77 ha.

Using the method of marginal utility value, the forest interest rate was established for pine stands growing in various types of forest sites. Depending on quality class, the forest interest rate for these stands in 2014 for quality class Ia was $3.19 \%$, quality class I $-3.03 \%$, II $-2.79 \%$, III $-2.52 \%$, IV $-2.23 \%$ and in the poorest site, that it, quality class $\mathrm{V}-1.58 \%$.

\section{CONCLUdING REMARKS AND DISCUSSION}

In the traditional approach, forestry economics is a science investigating how people cope with the scarcity and a lack of unlimited availability of forest goods. At present, the definitions of forest economy are more extensive and at the same time highly diverse. It is generally stressed that forest economy comprises all human activity connected with forest, which has the aim to provide sustainable optimal satisfaction of human needs for material and non-material forest goods.

Value is thus a multifaceted term and for this reason, forest economics uses a set of various categories of forest value. Two basic categories of value, with which we deal in economics, are connected with market value and non-market value. The market value is specified by the market as a result of interactions of supply and demand. Occasionally, market value is referred to in Polish as the exchangeable value and value in exchange. Nonmarket value is a value ascribed by consumers to a good or service, for which there is no real market (Płotkowski 2010). Ecosystem Services Valuation (ESV) now occupies a central place in both the political and academic agendas of biodiversity conservation (Centemeri 2015; Costanza 2002; Farley and Costanza 2010; Deng et al. 2011; Garcia-Llorente et al. 2011; Kates et al. 2001; Kaffashi et al. 2011; Shaw et al. 2011; Thompson et al. 2011). At present, attempts are being made at estimation of non-productive forest functions (Barrena et al. 2014; Campbell and Tilley 2014; Doherty et al. 2014; Luo and Zhang 2014; Shapiro and Báldi 2014), while there is no single, legally sanctioned method to evaluate the economic value of forests. Valuation of material functions of the forest, particularly the stand, is thus the primary problem in forestry economics, especially forestry accounting, resulting directly from current legal regulations.

In accordance with the monetary theory commonly accepted in free market economy and the assumptions of land rent, formulas were developed for the calculation of economic value of stands at any given age (Speidel 1967). In view of the fact that in practice it is difficult to reach the assumptions for a normal forest, static methods are widely criticised. The concept of time preference had hardly any relevance in developing the theory of the normal forest. Defenders of forest rent reject the idea of discounting in forestry. No time preference is assumed and simply the average annual cash flow is maximised.

Various arguments have been raised against discounting, such as ethical indefensibility (Ramsey 1928), depletion of natural resources (Clark 1973) and intergenerational equity (Brukas et al. 2001). Even if foresters believe that the calculations of interest rates have nothing to do with the practice of sustainable forestry, 
their actions are in accordance with the economic theory. Stands of different yield conditions are harvested at the same marginal interest rate, which leads to an optimal allocation of the standing volume. The ignorance of economic theory obviously does not prevent actions, according to this theory. This insight might be a basis for closer links between practical forestry and forest economic work in future (Möhring 2001).

At present, procedures for the application of income methods of forest valuation are not considered problematic and have been extensively described. Estimation of a suitable discount rate is not a trivial task when the experience of decision making under market economy conditions is absent (Brukas et al. 2001). As it has been previously mentioned, a difficulty here is posed by the establishment of an adequate interest rate. We may hardly agree with an opinion of Podgórski and Kikayi (1996) that the relationship between standing timber resources and the allowable annual cut refers directly to forest value, particularly at the current ecologicallyoriented approach to forest economy. Analyses of forest recovery in a number of European countries were conducted by Mather and others in the 1990s (Mather 1992; Mather and Needle 1998) and at its simplest they indicate the point, at which a country, as it becomes economically more prosperous, begins to gain forest area rather than losing it. Studies of forest transitions have been carried out by many researchers (André 1998; Foster 1992; Rudel et al. 2005; Staaland et al. 1998) leading both to more careful theorizing and a more general set of explanations of why forest transitions may occur (Rudel et al. 2005).

Moreover, we may not agree with an opinion that forest interest rate may be constant for all forest economies. Interest rate applied in forestry may not be a constant value, since it depends on a whole series of variables (time, location, rotation, economic situation, etc.). Moreover, various economic entities show differing profitability depending on tree species, site quality and forest management system (Riebel 1905). Martin (2013) also opposed uniformity of interest rates and considered them dependent not only on technical, but also on macroeconomic factors. He stated that interest rate is a resultant of objective moments (defined by stand growth increment) and subjective moments, defined by, for example, the objective pursued by a given forest economy. In view of the above, it seems justified to say that when determining forest interest rate, we need to consider fertility of forest sites and species composition of stands.

Nördlinger (1805) claimed that in reality, forests diverge from the model of the normal forest, thus we need to calculate the individual value of each stand. The total value of individual stands represents the value of the forest. Such an approach indicates the need to apply various interest rates for individual tree species.

The method (Eq. 6) proposed in this study may be used to calculate the forest interest rates for any species in any given country and for any administrative unit. An advantage of the proposed method for the calculation of forest interest rate is connected with the fact that revenue and costs used in the determination of forest interest rate are based on the current economic data. This information is available even if turnover in forest property is limited. It is of utilitarian value. The application of the proposed marginal method to establish forest interest rate makes it possible to include national or even local economic conditions in the valuation of stands connected with forestry and the wood industry. This contributes to the variation (by diverse values of interest rate) in stand value in individual countries and regions of a country.

The presented solution (Eq. 6) is a proposal, which needs to be verified by the scientific community. This method was preliminarily tested in Poland. Currently, the proposed methodological solutions should be verified under economic conditions found in other countries. In the case of the proposed solutions being accepted by the scientific community as a method to establish forest interest rate, the next step should be to establish a common forest valuation method. Uniform principles for the determination of economic value may influence the foundations of valuation for non-productive functions of forests.

Constantly improved scientific methods of valuation for economic and non-productive functions, including public functions of forests constituting external effects of forest economy, have not been yet fully utilised in economic practice in forestry. Forest functions, the value for which was established using various valuation methods, although adopting identical valuation measures (monetary units), may not be compared or totalled due to the application of different valuation criteria for these functions. The proposal of a uniform establishment of forest interest rates may be the first step in the 
establishment of uniform principles for forest valuation at least within comparable climatic and social conditions found in individual parts of the world.

\section{References}

André, M.-F. 1998. Depopulation, land-use change and landscape transformation in the French Massif Central. Ambio, 27 (4), 351-353.

Ansink, E., Hein, L., Hasund, K.P. 2008. To value functions or services? An analysis of ecosystem valuation approaches. Environmental Values, 17 (4), 489-503.

Barrena, J., Nahuelhual, L., Báez, A., Schiappacasse, I., Cerda, C. 2014. Valuing cultural ecosystem services: Agricultural heritage in Chiloé island, southern Chile. Ecosystem Services, 7, 66-75. http://doi. org/10.1016/j.ecoser.2013.12.005.

Brukas, V., Jellesmark Thorsen, B., Helles, F., Tarp, P. 2001. Discount rate and harvest policy: implications for Baltic forestry. Forest Policy and Economics, 2 (2), 143-156. http://doi.org/10.1016/S13899341(01)00050-8.

Calish, S., Fight, R.D., Teeguarden, D.E. 1978. How do nontimber values affect Douglas-fir rotations? Journal of Forestry, 76 (4), 217-221.

Campbell, E.T., Tilley, D.R. 2014. The eco-price: How environmental emergy equates to currency. Ecosystem Services, 7, 128-140. http://doi.org/10.1016/j. ecoser.2013.12.002.

Centemeri, L. 2015. Reframing Problems of Incommensurability in Environmental Conflicts Through Pragmatic Sociology: From Value Pluralism to the Plurality of Modes of Engagement with the Environment. Environmental Values, 24 (3), 299-320. http://doi.org/10.3197/096327114X13947900181158.

Chang, S. 1983. Rotation age, management intensity, and the economic factors of timber production: do changes in stumpage price, interest rate, regeneration cost, and forest taxation matter? Forest Science, 29, 267-277.Clark, C.W. 1973. The economics of overexploitation. Science, 181 (4100), 630-634.

Costanza, R. 2002. New editor for ecological economics. Ecological Economics, 42 (3), 351-352. http:// doi.org/10.1016/S0921-8009(02)00178-7.
Crocker, T.D. 2002. A short history of environmental and resource economics. In: Handbook of Environmental and Resource Economics (ed.: J.C.J.M. van den Bergh). Edward Elgar Publishing, Cheltenham, UK, 32-45.

Deng, H., Zheng, P., Liu, T., Liu, X. 2011. Forest Ecosystem Services and Eco-Compensation Mechanisms in China. Environmental Management, 48 (6), 1079-1085. http://doi.org/10.1007/s00267-0119742-0.

Doherty, E., Murphy, G., Hynes, S., Buckley, C. 2014. Valuing ecosystem services across water bodies: Results from a discrete choice experiment. Ecosystem Services, 7, 89-97. http://doi.org/10.1016/j. ecoser.2013.09.003.

Endres, M. 1919. Lehrbuch der Waldwertrechnung. Forststatic, 3.

Farley, J., Costanza, R. 2010. Payments for ecosystem services: from local to global. Ecological Economics, 69 (11), 2060-2068.

Faustmann, M. 1849. Berechnung des Wertes welchen Waldboden sowie noch nicht haubare Holzbestände für die Waldwirtschaft besitzen. Allgemeine ForstUnd Jagd-Zeitung, 15 (1849), 7-44.

Foster, D.R. 1992. Land-use history (1730-1990) and vegetation dynamics in central New-England, USA. Journal of Ecology, 80 (4), 753-772. http:// doi.org/10.2307/2260864.

Gaffney, M. 2008. Keeping land in capital theory - Ricardo, Faustmann, Wicksell, and George. American Journal of Economics and Sociology, 67 (1), 119-141. http://doi.org/10.1111/j.15367150.2007.00562.x.

Gan, J., Kolison, S.H., Colletti, J.P. 2001. Optimal forest stock and harvest with valuing non-timber benefits: a case of US coniferous forests. Forest Policy and Economics, 2 (2), 167-178. http://doi.org/10.1016/ S1389-9341(01)00051-X.

Garcia-Llorente, M., Martin-López, B., Diiaz, S., Montes, C. 2011. Can ecosystem properties be fully translated into service values? An economic valuation of aquatic plant services. Ecological Applications, 21 (8), 3083-3103.

Hartman, R. 1976. The harvesting decision whena standing forest has valuea. Economic Inquiry, 14 (1), 52-58. 
Holland, A. 2011. What do we do about bleakness? Environmental Values, 20 (3), 315-321.

Kaffashi, S., Shamsudin, M.N., Radam, A., Rahim, K.A., Yacob, M.R., Muda, A., Yazid, M. 2011. Economic valuation of Shadegan International Wetland, Iran: notes for conservation. Regional Environmental Change, 11 (4), 925-934. http://doi. org/10.1007/s10113-011-0225-x.

Kates, R.W., Clark, W.C., Corell, R., Hall, J.M., Jaeger, C.C., Lowe, I. 2001. Sustainability science. Science, 292 (5517), 641-642.

Lehr, J., Borggreve, B. 1879. Die Forstreinertragslehre, insbesondere die sog. forstliche Statik Prof. Dr. G. Heyers nach ihrer wissenschaftlichen Nichtigkeit und wirthschaftlichen Gefährlichkeit Oberförster in Bonn, Lehrer der Forstwissenschaft an der mit der Universität Bonn v. JSTOR.

Lowry, S.T. 1965. The Classical Greek Theory of Natural Resource Economics. Land Economics, 41 (3), 203-208. http://www.jstor.org/stable/3144852.

Luo, D., Zhang, W. 2014. A comparison of Markov model-based methods for predicting the ecosystem service value of land use in Wuhan, central China. Ecosystem Services, 7, 57-65. http://doi. org/10.1016/j.ecoser.2013.11.001.

Manley, B., Bare, B.B. 2001. Computing maximum willingness to pay with Faustmann's formula: some special situations from New Zealand. Forest Policy and Economics, 2 (2), 179-193. http://doi. org/10.1016/S1389-9341(01)00044-2.

Martin, H. 2013. Die forstliche Statik: Ein Handbuch für leitende und ausführende Forstwirte sowie zum Studium und Unterricht. Springer-Verlag.

Martinez-Alier, J. 2001. Mining conflicts, environmental justice, and valuation. Journal of Hazardous Materials, 86 (1), 153-170.

Martinez-Alier, J., Munda, G.,O’Neill, J. 1998. Weak comparability of values as a foundation for ecological economics. Ecological Economics, 26 (3), 277-286.

Mather, A.S. 1992. The forest transition. Area, 24, 367-379.

Mather, A.S., Needle, C.L. 1998. The forest transition: a theoretical basis. Area, 30 (2), 117-124.

Mcconnell, K.E., Daberkow, J.N., Hardie, I.W. 1983. Planning timber production with evolving prices and costs. Land Economics, 59 (3), 292-299. http:// doi.org/10.2307/3145731.

Möhring, B. 2001. The German struggle between the "Bodenreinertragslehre" (land rent theory) and "Waldreinertragslehre" (theory of the highest revenue) belongs to the past - but what is left? Forest Policy and Economics, 2 (2), 195-201. http://doi. org/10.1016/S1389-9341(01)00049-1.

Molenda, T. 1945. Wycenianie nieruchomości leśnych w ekonomii i w technice. Koło Leśników UP Poznań.

Newman, D.H., Gilbert, C.B., Hyde, W.F. 1985. The optimal forest rotation with evolving prices. Land Economics, 61 (4), 347-353.

Nördlinger, J.S. 1805. Versuch den Werth der Waldungen zu bestimmen. Diana, 3, 363-400.

Pearce, D.W., Seccombe-Hett, T. 2000. Economic valuation and environmental decision-making in Europe. Environmental Science and Technology, 34 (8), 1419-1425.

Piekutin, J., Skreta, M. 2012. Ekonomiczny wiek rębności drzewostanów sosnowych. Sylwan, 156 (10), 741-749.

Płotkowski, L. 2010. Gospodarka leśna w badaniach ekonomiki leśnictwa. Rocznik Nauk Rolniczych, Seria $G, 97,110-120$.

Podgórski, M., Kikayi, R.P. 1996. Próba określenia produkcyjności i produktywności lasu za pomocą wskaźników technicznych i ekonomicznych, na przykładzie nadleśnictw Regionalnej Dyrekcji Lasów Państwowych w Szczecinie. Prace Komisji Nauk Rolniczych i Komisji Nauk Leśnych. Poznańskie Towarzystwo Przyjaciót Nauk, 82, 125-133.

Price, C. 1987. Environmental benefits and optimal rotation: Comment on Johansson and Loefgren. Journal of Environmental Management, 25 (3), 215-218.

Ramsey, F.P. 1928. A mathematical theory of saving. The Economic Journal, 38 (152), 543-559.

Riebel, F. 1905. Die Wertermittlung der Obstbäume und anderer Einzelbäume. Fromme, 88 pp.

Rudel, T.K., Coomes, O.T., Moran, E., Achard, F., Angelsen, A., Xu, J., Lambin, E. 2005. Forest transitions: towards a global understanding of land use change. Global Environmental Change, 15 (1), 23-31. http://doi.org/10.1016/j.gloenvcha. 2004.11.001. 
Shapiro, J., Báldi, A. 2014. Accurate accounting: How to balance ecosystem services and disservices. Ecosystem Services, 7, 201-202. http://doi.org/10.1016/j. ecoser.2014.01.002.

Shaw, M.R., Pendleton, L., Cameron, D.R., Morris, B., Bachelet, D., Klausmeyer, K., Roehrdanz, P.R. 2011. The impact of climate change on California's ecosystem services. Climatic Change, 109 (1), 465-484. http://doi.org/10.1007/s10584-011-0313-4.

Spangenberg, J.H., Settele, J. 2016. Value pluralism and economic valuation - defendable if well done. Ecosystem Services, 18, 100-109. http://doi. org/10.1016/j.ecoser.2016.02.008.

Staaland, H., Holand, Ø., Nellemann, C., Smith, M. 1998. Time scale for forest regrowth: abandoned grazing and agricultural areas in southern Norway. Ambio, 27, 456-460.

Tahvonen, O., Salo, S. 1999. Optimal Forest Rotation within SituPreferences. Journal of Environmental Economics and Management, 37 (1), 106-128. http://doi.org/10.1006/jeem.1998.1055.
Thompson, I.D., Okabe, K., Tylianakis, J.M., Kumar, P., Brockerhoff, E.G., Schellhorn, N.A., Nasi, R. 2011. Forest Biodiversity and the Delivery of Ecosystem Goods and Services: Translating Science into Policy. Bioscience, 61 (12), 972-981. http://doi. org/10.1525/bio.2011.61.12.7.

Vankooten, G.C., Binkley, C.S., Delcourt, G. 1995. Effect of carbon taxes and subsidies on optimal forest rotation age and supply of carbon services. American Journal of Agricultural Economics, 77 (2), 365-374. http://doi.org/10.2307/1243546.

Viitala, E.-J. 2016. Faustmann formula before Faustmann in German territorial states. Forest Policy and Economics, 65, 47-58. http://oi.org/10.1016/j. forpol.2015.11.004.

Zając, S., Świętojański, A. 2002. Podstawy metodyczne wyceny lasu. Sylwan, 3 (146), 5-20.

Zydroń, A., Szafrański, C., Korytowski, M. 2012. Koncepcje określania wysokości leśnej stopy procentowej. Sylwan, 156 (5), 333-342. 